\title{
ROLA PIELĘGNIARKI W OPIECE I REHABILITACJI CHOREJ PO ZABIEGU ENDOPROTEZOPLASYKI STAWU BIODROWEGO
}

\section{THE ROLE OF THE NURSE IN NURSING AND REHABILITATION IN PATIENT AFTER HIP REPLACEMENT SURGERY}

\author{
Remigiusz Gołąbek \\ Pielęgniarz i Fizjoterapeuta \\ Zakład Rehabilitacji w Centrum Radomia \\ DOI: https://doi.org/10.20883/pielpol.2017.42
}

\begin{abstract}
STRESZCZENIE
W niniejszej pracy opisano postępowanie pielęgnacyjne pacjentki po zabiegu endoprotezoplastyki stawu biodrowego, uwzględniając przy tym profesjonalną fizjoterapię. Podmiotem badania jest 60-letnia kobieta, leczona operacyjnie po urazie, jakim był upadek w mieszkaniu.

Celem głównym pracy jest próba zbadania, jak istotną rolę spełnia pielęgniarka $w$ opiece, włączając również rehabilitację po zabiegu wymiany stawu biodrowego. Ukazano istotę jej pracy jako osoby, która nie tylko pielęgnuje pacjentkę po powrocie do domu, ale także pełni istotną rolę w zakresie nauki prawidłowego poruszania się, oraz właściwego wykonywania podstawowych czynności dnia codziennego. To ona instruuje podopieczną, czego należy unikać, aby nie doszło do uszkodzenia wszczepionej protezy. Przedstawiono także, jakie negatywne konsekwencje może nieść za sobą brak ruchu: przykurcze mięśniowe, obrzęki kończyn, a także stan depresyjny, który miał miejsce w przedstawionym przypadku. Wykazano również, że zaangażowanie pielęgniarki przyniosło pozytywne efekty dla pacjentki zarówno w opiece szpitalnej, jak i i domowej.
\end{abstract}

SŁOWA KLUCZOWE: rehabilitacja, pielęgniarstwo, opieka, endoproteza.

\section{Wprowadzenie}

W XXI w. oczekiwania pacjentów wobec personelu medycznego znacznie wzrosły. Na skutek zwiększenia swoich kwalifikacji stały się jedną z bardziej szanowanych i cenionych medycznych grup zawodowych - zarówno w kraju, jak i za granicą.

Polska pielęgniarka, chcąc zapewnić pacjentom jak najlepszą pomoc, niejednokrotnie kończy liczne kursy i specjalizacje, aby zaspokoić potrzeby chorych. $\mathrm{Na}$ jej kompetencje składają się: wiedza, doświadczenie, empatia i zrozumienie oraz autonomia i profesjonalizm [1]. Niekiedy po wypisaniu pacjenta ze szpitala jest ona gwarantem jego szybkiego powrotu do zdrowia. W wielu domach poza swoimi podstawowymi obowiązkami pełni

\begin{abstract}
This paper describes the process of nursing a patient after the endoprosthetic hip replacement surgery, taking into consideration professional physiotherapy. The subject of the research was a 60-year-old woman treated surgically after she had sustained an injury when falling down at home.

The main goal of this research was to try and investigate the importance of the role a nurse has in nursing and rehabilitating patients after the endoprosthetic hip replacement surgery. This work shows the importance of a nurse as a person who nurses the patient when he or she is back at home, as well as the one who acts as a physiotherapist who has to teach the patient how to move in a correct way, how to perform basic tasks and what to avoid in order not to loosen or dislocate the replacement hip. Also, the work presents the negative consequences the lack of exercise might have, i.e. muscular contractures, limb swelling, and depressive state, which was present in this case. Moreover, the work points out that the commitment of the nurse had a positive effect on the patient in both hospital and home care.
\end{abstract}

KEYWORDS: rehabilitation, nursing, care, endoprosthesis.

także rolę psychologa, edukatora oraz fizjoterapeuty ${ }^{*}$. To na nią spada ogromna odpowiedzialność dbania o stan podopiecznego, edukowania rodziny czy nauki prawidłowych nawyków żywieniowych oraz posturalnych.

W pracy została przedstawiona istotna rola pielęgniarki w powrocie do zdrowia i sprawności fizycznej samotnej pacjentki po wszczepienia endoprotezy stawu biodrowego, u której występuje stan depresyjny będący następstwem operacji.

W pierwszej części omówiono: czym jest endoproteza oraz jakie są wskazania do zabiegu. W kolejnym rozdziale przedstawiono metodologię, cel pracy, opis stanu psychofizycznego pacjentki oraz narzędzia i me-

Fizjoterapeuta - Rehabilitant 
tody badawcze. W części trzeciej poruszone zostały problemy pielęgnacyjne (włącznie z rehabilitacją) oraz umiejscowiono pielęgniarkę w zespole terapeutycznym, jako jego niezbędne ogniwo. Ostatnią część pracy stanowi zakończenie, wyniki i wnioski oraz bibliografia.

\section{Czym jest endoproteza?}

Endoproteza jest to sztuczny staw zbudowany z kuli (głowy), na końcu której znajduje się trzpień oraz panewki.

W medycynie można spotkać kilka odmian endoprotez stawu biodrowego, które ze względu na wskazania można podzielić na całkowite i częściowe.

Przy zastosowaniu tej pierwszej na elementy sztuczne trzeba zamienić głowę kości udowej oraz panewkę, natomiast przy częściowej endoprotezie wymianie ule- ga tylko głowa, która jest zastępowana sztuczną, a panewka pozostaje nienaruszona.

W ciągu ostatnich dziesięcioleci zmienił się sposób mocowania sztucznych stawów.

Pierwowzorem były protezy mocowane poprzez użycie tzw. cementu kostnego, ale okazał się on zbyt szkodliwy. Został zastąpiony cementem akrylowym, ale on również nie był wolny od wad.

Obecnie wykorzystuje się protezy bezcementowe. Panewkę i trzpień, czyli zewnętrzną powierzchnię endoprotezy pokrywa się hydroksyapatytem (naturalnym mineralnym składnikiem kości). Ma ona dużą powierzchnię, która staje się szorstka, a z upływem czasu w jej pory wrasta kość - zapewniając protezie stabilność [2].

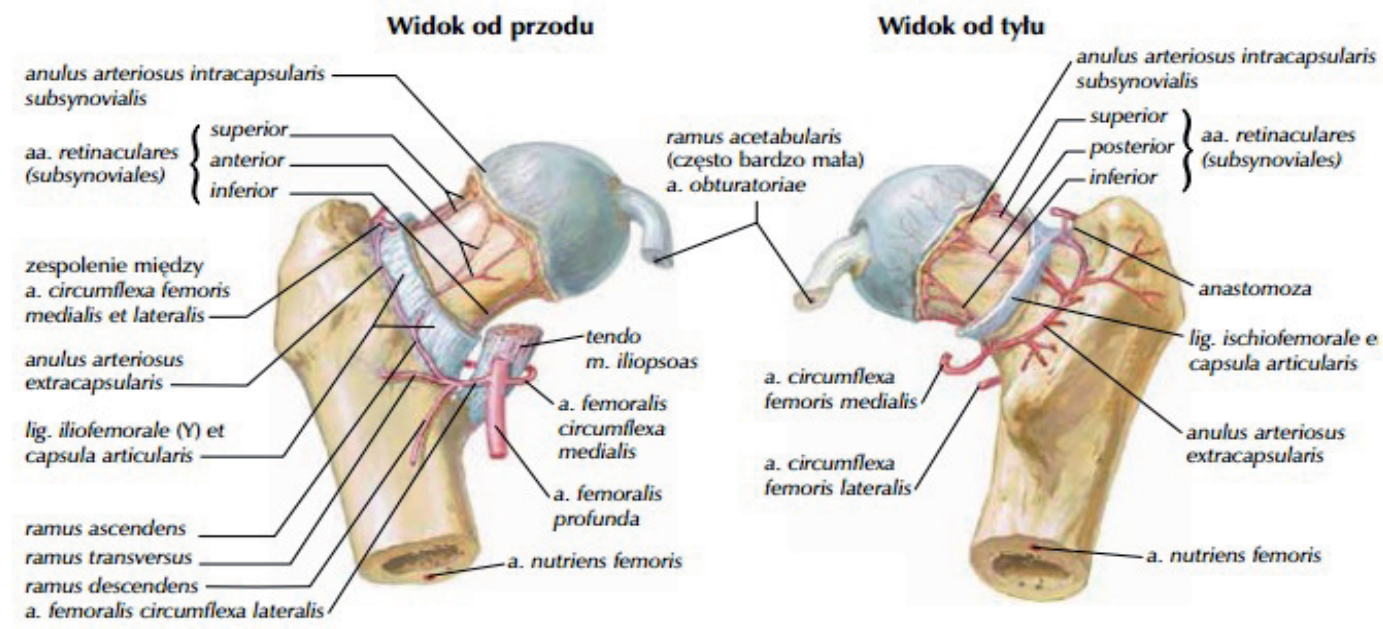

Rycina 1. Anatomia stawu biodrowego - widok z przodu i z tyłu

Figure 1. Hip replacement anatomy - front view and rear view

Źródło/Source: Green Walter B. Ortopedia Nettera. Artur Dziak red. wyd. I pol. Wrocław: Elsevier Urban \& Partner; 2007, s. 344
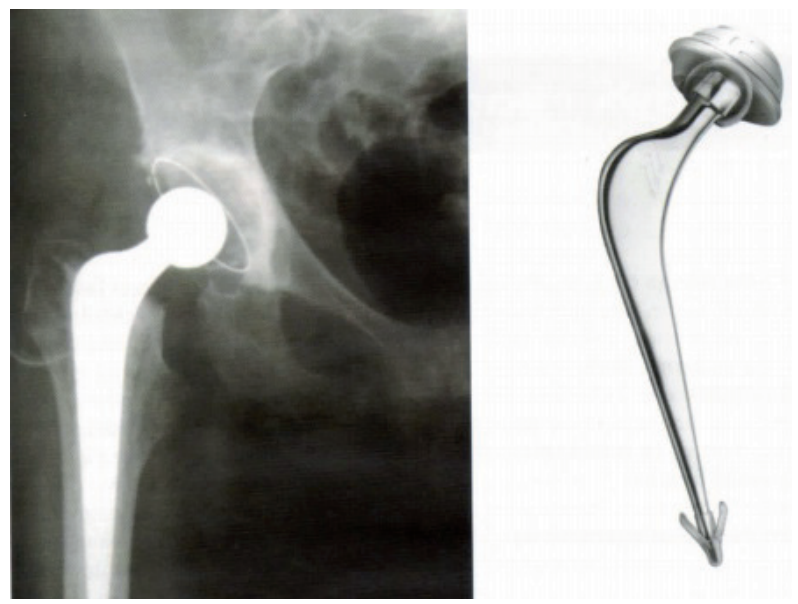

Rycina 2. Endoproteza cementowa [4]

Figure 2. Endoprosthesis of a cemented hip system

Źródło/Source: Pozowski A. Alloplastyka stawu biodrowego. Wrocław: Górnicki Wydawnictwo Medyczne 2011, s. 32 


\section{Wskazania do endoprotezoplastyki stawu biodrowego}

Celem operacji jest przede wszystkim zniesienie bólu i przywrócenie prawidłowych funkcji stawu biodrowego. Każda czynność, która była ograniczona przez sztywność i bolesność stawu, może zostać przywrócona do prawidłowego funkcjonowania za pomocą dobrze wykonanego zabiegu endoprotezoplastyki [5].

Choroby, które prowadzą do uszkodzenia stawu, a tym samym są wskazaniem do wymiany stawu biodrowego, to:

- choroba reumatyczna;

- choroba zwyrodnieniowa stawu biodrowego;

- $\quad$ przebyte złamanie miednicy lub bliższego końca kości udowej;

- guzy kości;

- $\quad$ martwica głowy kości udowej.

Objawami świadczącymi o konieczności wykonania zabiegu endoprotezoplastyki są:

- ból, który nie pozwala zasnąć, ale także pojawia się w środku nocy;

- $\quad$ trudność z chodzeniem po schodach;

- trudności ze wstaniem z pozycji siedzącej;

- niewielka ulga lub brak ulgi po środkach przeciwbólowych;

- $\quad$ ograniczenia dnia codziennego [6].

\section{Materiał, cel i metody}

\section{Cel główny}

Celem głównym pracy jest ukazanie roli pielęgniarki w opiece nad pacjentką po zabiegu endoprotezoplastyki stawu biodrowego.

Do tak sformułowanego celu pracy sprecyzowano następujący problem badawczy: zbadanie, jaką rolę spełnia pielęgniarka $\mathrm{w}$ procesie pielęgnowania, uwzględniając przy tym czynności rehabilitacyjne, których wymaga chora po wymianie stawu biodrowego.

\section{Metody, techniki i narzędzia badawcze}

W niniejszej pracy zastosowana została technika indywidualnego przypadku (studium przypadku). W celu zebrania danych, identyfikacji problemów pielęgnacyjnych, sposobu ich rozwiązania oraz dokonania efektywności podjętych działań zostały zastosowane poniższe techniki badawcze:

- $\quad$ wywiad pielęgniarski;

- obserwacja pielęgniarska;

- $\quad$ analiza dokumentacji medycznej;

- pomiar parametrów życiowych.

Narzędzia badawcze, zastosowane w pracy:

- $\quad$ kwestionariusz wywiadu pielęgniarskiego;
- $\quad$ historia choroby pacjenta;

- karta gorączkowa;

- $\quad$ karta planu opieki i realizacji działań pielęgniarskich;

- $\quad$ arkusz karty wkłuć;

- $\quad$ karta zleceń lekarskich;

- karta obserwacyjna.

\section{Opis obszaru badań}

Badanie podmiotowe i przedmiotowe przeprowadzone podczas wizyty w domu pacjentki. Podczas wywiadu chora została poinformowana, w jakim celu gromadzone są informacje, oraz wyraziła pisemną zgodę na ich wykorzystanie.

\section{Charakterystyka pacjenta}

Pacjentka - kobieta w wieku 60 lat zamieszkała w Radomiu, w budynku wielorodzinnym na pierwszym piętrze, bez windy. Mąż nie żyje, nie posiada dzieci ani rodziny. Opiekę sprawują opiekunki medyczne i pielęgniarka środowiskowa. Warunki mieszkaniowe oraz materialne ocenione jako dobre. Mieszkanie dostosowane do potrzeb. Chora rozmowna, unika jednak rozmów na temat swojego stanu zdrowia - nie jest pogodzona z sytuacją, w jakiej się znalazła, gdyż jej obecny stan ogranicza wykonywanie pewnych czynności (długi spacer, jazda na rowerze), które niegdyś bardzo lubiła. Obecnie jest na rencie, nie posiada nałogów.

Na skutek wypadku, jaki miał miejsce w mieszkaniu w marcu 2014 r., doznała urazu stawu biodrowego. Po zdarzeniu pacjentka poddana została leczeniu szpitalnemu - lekarz zdecydował o wykonaniu zabiegu endoprotezoplastyki stawu biodrowego. Po wypisie opiekę zaczęły sprawować wynajęte opiekunki medyczne. Od czasu zabiegu nastrój podopiecznej uległ obniżeniu, co wywołało negatywne konsekwencje. Na skutek długotrwałej pozycji leżącej zaczęły występować powikłania ze strony układu mięśniowego. Pojawiły się przykurcze w stawach kolanowych (kąt około 45 stopni). Z każdym dniem niechęć pacjentki do poruszania się ulega zwiększeniu. Stan fizyczny jest spowodowany złym stanem psychicznym. Obniżony nastrój (stan depresyjny), który zaczął pojawiać się po zabiegu, utrzymuje się do dnia dzisiejszego. Pacjentka jest całkowicie uzależniona od osób trzecich, od czasu zabiegu jest pozbawiona chęci życia. Wymaga pomocy przy poruszaniu się. Mimo licznie podejmowanych prób przekonania chorej, że zły stan fizyczny jest uwarunkowany stanem psychicznym, zespół terapeutyczny napotyka silny opór.

Podczas wywiadu wartość RR 140/75 mmHg, tętno 80 u/min. Występuje obrzęk kończyn dolnych. Mimo długotrwałej pozycji leżącej nie zaobserwowano duszności ani kaszlu. Kontakt słowno-logiczny zachowany, 
pojawiają się zaburzenia snu spowodowane stanem depresyjnym.

Okularów używa jedynie do czytania, słuch, czucie dotyku i temperatury prawidłowe. Ze strony układu pokarmowego: pragnienie i łaknienie zaburzone - brak apetytu, odżywianie doustne, dieta lekkostrawna - spożywana w małych ilościach. Połykanie prawidłowe, występują liczne ubytki w uzębieniu. Defekacja prawidłowa, występują jednak sporadyczne zaparcia - spowodowane zbyt małą ilością ruchu. Diureza prawidłowa.

Skóra, włosy, paznokcie czyste. Pacjentka nosi pielucho-majtki i wymaga pomocy przy ich zmianie. Z chorób współistniejących występuje nadciśnienie tętnicze.

Wzrost pacjentki $170 \mathrm{~cm}$, waga 63 kg. Współczynnik BMI - 21 - waga prawidłowa. Ryzyko wystąpienia odleżyn bardzo duże (13 wg skali Norton).

\section{Problemy pielęgniarskie występujące u pacjentki}

Problem 1. Obniżony nastrój - niechęć do samodzielnego poruszania się.

Cel opieki: Ożywienie pacjentki - przywrócenie chęci życia.

Plan działań:

- przekonanie pacjentki, że stan fizyczny jest spowodowany jej złym stanem psychicznym;

- rozmowa w celu poznania obaw i przyczyn złego samopoczucia chorej;

- zorganizowanie chorej wyjścia na spacer na wózku inwalidzkim i pokazanie piękna współczesnego świata;

- $\quad$ nauka w zakresie czynności higienicznych oraz pielęgnacyjnych zapewniających samoopiekę/ niezależność od osób trzecich;

- wizyty wolontariuszy w domu podopiecznej w celu poprawy nastroju;

- $\quad$ trening relaksacyjny Schultza;

- wprowadzenie ćwiczeń oddechowych torem piersiowym;

- w razie konieczności wizyta psychiatry.

Problem 2. Brak apetytu i spadek masy ciała.

Cel opieki: Poprawa łaknienia i utrzymanie stałej wagi.

Plan działań:

- zastosowanie diety lekkostrawnej;

- $\quad$ zachęcanie do spożycia posiłków;

- $\quad$ ćwiczenia fizyczne, które wzmogą łaknienie;

- $\quad$ wspólne ustalanie składu posiłków;

- zachęcanie do wspólnego przygotowywania potraw;

- urozmaicenia w diecie lekkostrawnej;

- $\quad$ estetyczne przygotowanie dań;

- $\quad$ kontrola przyjmowania posiłków;

- $\quad$ posiłki w małych ilościach a częściej przyjmowane;
- $\quad$ zapewnienie wygodnej pozycji w trakcie konsumpcji;

- $\quad$ przekonanie o konieczności zmiany diety i jej znaczeniu dla zdrowia.

Problem 3. Nadciśnienie tętnicze.

Cel opieki: Obserwacja pod kątem nadciśnienia.

Plan działań:

- $\quad$ pomiar tętna i ciśnienia krwi;

- podawanie leków obniżających RR na zlecenie lekarza;

- $\quad$ wykonanie EKG po konsultacji z lekarzem;

- przekonanie do umiarkowanych spacerów.

Problem 4. Ból towarzyszący poruszaniu się.

Cel opieki: Zmniejszenie lub zniesienie bólu.

Plan działań:

- ćwiczenia usprawniające, dostosowane do stanu pacjentki;

- podanie leków przeciwbólowych na zlecenie lekarza;

- $\quad$ wprowadzenie fizykoterapii (np. okład zimny);

- zastosowanie odpowiednich pozycji ułożeniowych zmniejszających ból.

Problem 5. Brak samodzielności w wykonywaniu czynności w zakresie higieny osobistej.

Cel opieki: Zwiększenie poziomu samodzielności.

Plan działań:

- $\quad$ zachęcenie pacjentki do samodzielnego mycia;

- $\quad$ pomaganie przy zmianie bielizny osobistej i pościelowej;

- $\quad$ pomoc w założeniu pielucho-majtek;

- próba samodzielnej kąpieli chorej przy obecności i pomocy opiekunki.

Problem 6. Trudność w samodzielnym zaspokajaniu potrzeb fizjologicznych.

Cel opieki: Uzyskanie samodzielności.

Plan działań:

- próba przekonania i nauczenia pacjentki samodzielnego korzystania z ubikacji;

- $\quad$ podanie basenu w sytuacjach koniecznych;

- zapewnienie intymności;

- diureza - obserwacja ilości oraz koloru moczu;

- mobilizowanie pacjentki do samodzielności w zakresie zaspokajaniu potrzeb fizjologicznych;

- zastosowanie pielucho-majtek tylko gdy pacjentka pozostaje sama w domu.

Problem 7. Obrzęk kończyn

Cel opieki: Zapobieganie zastojowi limfy i niedopuszczenie do powikłań ze strony układu limfatycznego i krwionośnego. 
Plan działań:

- $\quad$ wprowadzenie ćwiczeń usprawniających;

- $\quad$ pionizacja i uruchomienie pacjentki;

- $\quad$ ułożenie kończyn w pozycji przeciwobrzękowej w łóżku;

- obserwacja obrzęków;

- $\quad$ częste zmiany pozycji;

- w razie nasilenia obrzęków wprowadzenie fizykoterapii i masażu limfatycznego;

- $\quad$ kontrolowanie płynów przyjętych i wydalonych;

- obserwacja stanu chorej;

- konsultacja z lekarzem.

Problem 8. Zwiększone ryzyko wystąpienia odleżyn na skutek długotrwałej pozycji leżącej.

Cel opieki: Zmniejszenie ryzyka wystąpienia odleżyn oraz niedopuszczenie do ich wystąpienia.

Plan działań:

- $\quad$ rozmowa i uzmysłowienie pacjentce ryzyka wystąpienia odleżyn i ich negatywnych konsekwencji;

- $\quad$ wyjaśnienie chorej zalet ćwiczeń wzmacniających i gimnastyki usprawniającej;

- częste zmiany pozycji;

- $\quad$ kontrola i pielęgnowanie skóry;

- odciążenie miejsc narażonych na ucisk;

- toaleta ciała;

- dokładne osuszanie i nawilżanie skóry maściami i kremami;

- $\quad$ profilaktyczne zastosowanie materaca przeciwodleżynowego;

- $\quad$ pionizacja chorej;

- $\quad$ pomoc przy poruszaniu się z balkonikiem.

Problem 9. Okresowe zaparcia spowodowane małą ilością pokarmów oraz brakiem ruchu.

Cel opieki: Uregulowanie wypróżnień.

Plan działań:

- ustalenie z pacjentką przyczyn zaburzeń wypróżniania;

- $\quad$ uzmysłowienie chorej, jakie pozytywne konsekwencje mogą mieć ćwiczenia fizyczne;

- kontrola częstości oddawania stolca;

- $\quad$ wprowadzenie do posiłków składników bogatych w błonnik;

- $\quad$ wykonanie lewatywy przeczyszczającej;

- $\quad$ poinformowanie lekarza o wystąpieniu zaparć;

- $\quad$ podanie środka przeczyszczającego na zlecenie lekarza.

Problem 10. Okresowe parestezje kończyn dolnych na skutek zaburzonego krążenia z powodu unieruchomienia.

Cel opieki: Zmniejszenie lub usunięcie dyskomfortu pacjentki.
Plan działań:

- rozmowa i przekonanie o skuteczności ćwiczeń leczniczych;

- $\quad$ wprowadzenie ćwiczeń usprawniających;

- masowanie kończyny podczas wystąpienia odrętwień;

- częsta zmiana pozycji;

- informowanie lekarza w przypadku zaobserwowania braku efektów powyższych działań.

Problem 11. Brak pełnego wyprostu w stawie kolanowym, ograniczający prawidłowy chód.

Cel opieki: Rozciągniecie przykurczonych mięśni.

Plan działań:

- uświadomienie negatywnych skutków braku ruchu i długotrwałej pozycji leżącej;

- $\quad$ poizometryczna relaksacja mięśni;

- nauka pacjentki samodzielnego rozciągania przykurczonych mięśni;

- zastosowanie kinesiotapingu w celu rozluźnienia napiętych mięśni;

- $\quad$ pionizacja i nauka prawidłowego chodu;

\section{Wyniki i wnioski}

\section{Pielęgniarka jako część zespołu terapeutycznego}

Powrót do zdrowia chorej nakłada na pielęgniarkę obowiązek działania nie tylko w sferze czysto pielęgniarskiej, ale również rozpoznania potrzeb biopsychospołecznych oraz dążenia do jak najszybszej i jak najwcześniejszej profesjonalnej rehabilitacji.

W celu osiągnięcia zadowalających rezultatów pielęgniarka powinna wykazywać się znajomością anatomii narządu ruchu, etiologii i patogenezy chorób, mieć wiedzę na temat zasad zapobiegania rozwojowi zniekształceń narządu ruchu oraz posiadać umiejętności z zakresu fizjoterapii. Chorą należy traktować kompleksowo, indywidualnie i interdyscyplinarnie.

Pielęgniarka wykorzystując swoje kwalifikacje pełni funkcję doradczą w zespole terapeutycznym i bierze czynny udział w powrocie pacjentki do zdrowia. Realizuje plan opieki tak, aby podtrzymać, przywrócić lub poprawiać stan zdrowia osoby cierpiącej. Działania powinny być prowadzone w taki sposób, aby nie dopuścić do pojawienia się powikłań oraz negatywnych skutków procesu chorobowego. Wszystkie działania muszą być sprecyzowane i nastawione na osiągnięcie maksymalnej sprawności psychicznej i fizycznej oraz na zapewnienie maksymalnego komfortu dalszego prawidłowego funkcjonowania.

We współczesnej medycynie okres hospitalizacji coraz bardziej się skraca. Nowoczesne metody leczenia i krótki czas pobytu na oddziale nakładają na zespół terapeutyczny (lekarza, pielęgniarkę, fizjoterapeutę, 
psychologa) obowiązek podejmowania spójnych działań, a także współdziałania w opiece i pielęgnacji nad podopieczną.

Do podstawowych zadań stawianych personelowi medycznemu należy: wybór sposobu operacji, rodzaju oprotezowania, a także usprawnienie i pielęgnowanie aby uzyskać zamierzony efekt i cel terapeutyczny.

Wspólne działanie wszystkich osób biorących udział w opiece jest gwarancją uzyskania najlepszych możliwych efektów leczenia [7]. Przede wszystkim należy określić sposoby rehabilitacji przed i po zabiegu, metody pielęgnacyjne oraz wskazówki i informacje mające pomóc pacjentce w samodzielnej egzystencji w życiu codziennym.

Głównym, podstawowym i nadrzędnym celem koncepcji pielęgnowania $w$ rehabilitacji jest zapewnienie osobie chorej czy niepełnosprawnej maksymalnej samodzielności oraz sprawności na danym etapie choroby.

Pielęgniarka nie tylko zastępuje i wyręcza osobę cierpiącą w pewnych czynnościach dnia codziennego, z którymi nie jest w stanie sama sobie poradzić, ale także pomaga jej w adaptacji do sytuacji zmienionej w wyniku choroby.

W pierwszej fazie pomaga chorej zaaklimatyzować się oraz oswoić z nową sytuacją. W kolejnej skupia uwagę na przygotowaniu do samoopieki i samopielęgnacji oraz uczy ją różnych sposobów radzenia sobie z niepełnosprawnością. To pielęgniarka odpowiada na pytania oraz pokazuje, jak żyć i odnaleźć się w nowej sytuacji. Każda osoba, która uczestniczy w procesie rekonwalescencji, musi ustalić z podopieczną dalszy przebieg współpracy i wypracować wspólną wizję jak najszybszego powrotu do zdrowia.

Wspólny cel determinuje wybór technik pielęgnacyjnych i terapii zajęciowej, które mają łączyć trening fizyczny z początkiem reintegracji i readaptacji społecznej. Terapia powinna łączyć zabawę z rehabilitacją, a także nauczyć samodzielności. Powinna mieć charakter aktywności twórczej. Osoba niepełnosprawna bądź częściowo sprawna po zabiegu operacyjnym na nowo uczy się takich czynności, jak samodzielne ubieranie się, mycie, czesanie, przygotowanie sobie posiłków oraz przemieszczanie się. Nauka tych czynności w większości przypadków leży w gestii pielęgniarki bądź członków rodziny, którzy opiekują się swoim krewnym. To na nich spoczywa odpowiedzialność nauczenia pacjentki, czego należy unikać, aby nie doprowadzić do obluzowania lub uszkodzenia protezy, oraz jak radzić sobie z barierami architektonicznymi. Pracę pielęgniarki cechuje profesjonalizm planowania, samodzielność w działaniu. Jej obowiązkiem jako osoby spędzającej najwięcej czasu w domu podopiecznej jest ko- ordynowanie i nadzorowanie całościowej opieki nad pacjentką.

\section{Zakończenie}

Celem niniejszej pracy jest ukazanie, jak ważną i znaczącą rolę odgrywa pielęgniarka w opiece nad pacjentką po endoprotezoplastyce stawu biodrowego, włączając $\mathrm{w}$ to również rehabilitację.

Posłużono się metodą indywidualnego przypadku, obserwacji pacjentki po urazie stawu, u której zastosowano całkowitą alloplastykę ${ }^{\star \star}$.

Zastosowane w pracy techniki badawcze to: wywiad, obserwacja pielęgniarska, analiza dokumentów, pomiar parametrów życiowych.

Jako narzędzia badawcze zastosowano: kwestionariusz wywiadu pielęgniarskiego, historię choroby, kartę gorączkową, kartę zleceń lekarskich, kartę planu opieki i realizacji działań pielęgniarskich.

Celem pracy była odpowiedź na pytanie: jak ważną rolę pełni pielęgniarka w opiece nad pacjentką po zabiegu endoprotezoplastyki stawu biodrowego.

Wiedza i umiejętności personelu medycznego odgrywają olbrzymią rolę w powrocie do sprawności osoby po zabiegu endoprotezoplastyki stawu biodrowego. Pielęgniarka jako pierwsza ma kontakt z chorą przy przyjęciu do szpitala, a także jest osobą, która spędza niezliczone godziny na wizytach domowych, ucząc ją samodzielnego poruszania się, samoobsługi czy przystosowania do nowej sytuacji, w jakiej się znalazła. Na nią spada często rola rehabilitantki, która musi pokierować podopieczną i wyedukować ją w ten sposób, aby nowy staw służył jej długie lata. To na jej rękach spoczywa odpowiedzialność za naukę prawidłowego wzorca chodu, w tym również poruszania się o kulach, a w razie zasłabnięcia czy potknięcia techniki bezpiecznego upadku.

Odpowiednie przygotowanie, wiedza i doświadczenie pielęgniarki wpływają na czas, w jakim chora przystosuje się do sytuacji oraz nauczy prawidłowo funkcjonować. To ona zajmuje się osobą cierpiącą podczas pierwszych najtrudniejszych chwil po zabiegu i w jej gestii jest niedopuszczenie do powikłań pooperacyjnych i zapobieganie wyrobieniu złych nawyków.

Pielęgniarka przez cały czas swojej aktywności zawodowej musi się doszkalać nie tylko z czynności stricte pielęgniarskich, ale również z dziedzin pokrewnych, takich jak fizjoterapia. Tylko wtedy, gdy posiądzie wiedzę z różnych obszarów medycyny, będzie w stanie pomóc całościowo i kompleksowo w każdym aspekcie zarówno pielęgnacyjnym, jak i rehabilitacyjnym. Sprawi to, że praca, którą wykonuje, przyniesie jej jeszcze

\footnotetext{
Alloplastyka - endoprotezoplastyka
} 
więcej satysfakcji i spełnienia, ponieważ, jak powiedział ojciec medycyny Hipokrates: „Zdrowie chorego najważniejszym prawem".

\section{Piśmiennictwo}

1. Stefańska W. Podstawowe zagadnienia współczesnej pielęgniarki w opiece zdrowotnej. Piel Pol 2004; 1-2: 4.

2. Ignasiak Z, Janusz A, Jarosińska A. Anatomia człowieka cz. I. Wrocław: wyd. AWF; 2001. 145.

3. Green Walter B. Ortopedia Nettera. Artur Dziak (red.) wyd. I pol. Wrocław: Elsevier Urban \& Partner; 2007. 344.

4. Pozowski A. Alloplastyka stawu biodrowego. Wrocław: Górnicki Wydawnictwo Medyczne 2011.32.

5. Garwadzka-Jodzis I. Koksartroza jako problem leczniczy i społeczny: przyczyny, zapobieganie, możliwości leczenia i problemy społeczno-zawodowe chorych z koksartrozą. Nowa Med 2003; 2: 48-51.

6. Pozowski A. Mam sztuczny staw biodrowy. Wrocław: Wyd. Med. Górnicki; 2011. 41-44.
7. Zimmermann-Górska I. Choroba zwyrodnieniowa stawów nowe spojrzenie? Pol Arch Med Wew 2008,118: 10-13.

Artykuł przyjęty do redakcji: 13.09 .2016

Artykuł przyjęty do publikacji: 23.11.2016

Źródło finansowania: Praca nie jest finansowana z żadnego źródła. Konflikt interesów: Autorzy deklarują brak konfliktu interesów.

Adres do korespondencji:

Remigiusz Gołąbek

ul. Bolesława Chrobrego 28/31

26-600 Radom

tel.: 600447765

e-mail: remigiusz-golabek@wp.pl

Zakład Rehabilitacji w Centrum Radomia 